\title{
The Relationship among Export, Import, Capital Formation and Economic Growth in Malaysia
}

\author{
Masoud Albiman $\mathrm{Md}^{1 *}$ and Suleiman $\mathrm{NN}^{2}$
}

${ }^{1}$ Department of Economics and Management Science, Universiti Sultan Zainal Abidin, Malaysia \& Zanzibar Revenue Board (ZRB), Zanzibar-Tanzania ${ }^{2}$ Department of Commerce and Marketing, Ministry of Trade, Zanzibar-Tanzania

\begin{abstract}
This study examine about the empirical question whether there is dynamic relationship among economic growth, export and import. Meanwhile, the objective of this study is to examine dynamic relationship among export- import and domestic investment. This study used time series data from 1967-2010 and VAR analysis. For the cointegration test we found no long run relationship among the interested variables. For causality analysis, export ratio and economic growth granger cause domestic investment. The impulse response function show that, the economic growth responds both positive and negative way depending on time period, due to the shock of domestic investment, import and export. Meanwhile because Malaysia is an open economy, to ensure effectively utilization of domestic resources, reforms of new policies to ensure that, at least two variables either import, export or domestic investment re enforce each other in promoting economic growth over long run is needed.
\end{abstract}

Keywords: Export; VAR; Granger causality; Import economic growth; Malaysia

\section{Introduction}

\section{The introduction of the on the dynamic relationship among economic growth, import and export}

From the theories of international trade since the study of Adam S et al. [1], it has been argued that, trade plays an important role in national wealth of the nations (capital formation). Furthermore, trade increases specialization in productions which leads to the efficient productions and optimum allocations of resources. Furthermore, the neo classical growth theories led by Solow [2] insisted that, trade (import and export) was a main determinant of growth and has long run relationship with economic growth. To strength the relationship between export and economic growth, during 1960s export led hypothesis received special attention, after the rapid increase in economic growth in East Asian Countries. It was believed that, the economic prosperity in East Asian Countries was influenced by the outward oriented policies. This situation is termed as Asian "miracle" led by Malaysia, Thailand as well as the four "tigers" namely Hong Kong, Taiwan, Korea and Singapore.

From this fact, vast group of economists had skeptical views toward the exports, as it was seen as the main engine of the economic growth. It is believed that, export through relieving the constraints of foreign exchange reserves, will increase competition in production, and in turn will lead to efficiency in productions and optimum allocation of resources. This would result to economies of scale through specializations in productions and promoting the diffusion of advanced technology [3-5]. Furthermore, the export growth relationship received a special priority in modeling the economic growth by the World Bank report [6].

Vast empirical literatures during 1980s until late 1990s examined the causality relationships between export and economic growth using the traditional granger causality test, bivariate systems which resulted to spurious results [7]. Furthermore, they faced misspecification problem ${ }^{1}$. Nevertheless, at the early of 2000s several studies insisted on the role of imports in determining the impact of export in economic growth. The

${ }^{1}$ The studies of 1970 s had not considered the test of unit root and co integrations Furthermore for more weakness these studies the reader should refer to ( Love and Chandra, 2005, Hossain et al., 2009). justified reasons for including imports as important variable, is due to the interactions of import and exports in determining the economic growth. Several studies suggested that, the imports are more important for those countries which are based on manufacturing industries or export oriented [8]. For example, if the country has enough foreign exchange, it can import high quality goods and services which in turn, increase productivity in domestic economy and promote more exports [9]. On the other hand, the imports of capital goods, intermediate goods and inputs and advanced technology can expand the capacity for utilization of domestic resources and production which lead to higher exports.

Furthermore, if we consider the endogenous growth theory, it emphasizes the role of imports in economic growth $[10,11]$. The theory suggests that, imports can attract foreign technology into the domestic economy and increase the availability of intermediate goods and inputs including machines, human capitals, skilled labors, equipment which in general increase productivity in the economy. In this case, imports received considerable attention in determining the long run economic growth especially for developing countries.

Even so, one key subject is ignored in determining the relationship between export and economic growth which is capital formation. This situation necessitates the need for the new empirically justifications which is the main purpose our study. Capital formations refer to the net additions of (physical) capital stock in the economy, which present the real picture of investment where by the goods and services are produced

*Corresponding author: Masoud Albiman Md, Department of Economics and Management Science, Universiti Sultan Zainal Abidin, Malaysia \& Zanzibar Revenue Board (ZRB), Zanzibar-Tanzania, Tel: +919668 8888; E-mail: albimani1966@hotmail.com

Received February 25, 2016; Accepted April 15, 2016; Published April 19, 2016

Citation: Albiman M, Suleiman NN (2016) The Relationship among Export Import, Capital Formation and Economic Growth in Malaysia. J Glob Econ 4: 186. doi:10.4172/2375-4389.1000186

Copyright: @ 2016 Albiman M, et al. This is an open-access article distributed under the terms of the Creative Commons Attribution License, which permits unrestricted use, distribution, and reproduction in any medium, provided the original author and source are credited. 
and present growth of "real economy". ${ }^{2}$ Capital formations (investment) can have relationship with the exports, because when the investment demand increases, the export demand also rises. In the same case, Young argued that, besides export, rapid increases in economic growth of Newly Industrialized Countries (NICs) were highly contributed due to the development of the investment policies. Specifically, the endogenous growth theories have shown that, export, import capital formation and economic growth have long run relationship with the economic growth. This needs empirical justifications especially for the rapid developing countries like Malaysia.

\section{Research Objective}

The general objective of this study is to investigate the dynamic relationship among economic growth, export and import. Subsequently, specific objective of this study are:

- To examine if there is long run relationship among economic growth, export and import

- To examine the causality relationship among economic growth, export and import

- To investigate the impulse response effect among the economic growth, export and import

\section{Literature Review}

\section{Previous studies on export, import and economic growth}

Since the review of literature has shown that import is the main variable in modeling export growth relationship, many studies examined the relationship among export, import and economic growth. These studies rose since early 2000s. Baharumshah and Rashid [9] found that, economic growth causes exports of manufacturing goods. However, they found feedback causal relationship between economic growth and exports for both manufacturing and agricultural products. Moreover, Awokuse [12] found that, there is bidirectional causality relationship between export and economic growth in Bulgaria. However, they found unidirectional causality relationship from imports to economic growth in Czech Republic and Poland. Furthermore, the study suggested that, the exclusion of imports in determining the role of export in economic growth may cause misleading in conclusion. Ugur supported Awokuse [12] as the study found the unidirectional causality from economic growth to both import of consumer goods and other goods in Turkey. Furthermore, Hossain et al. [13] found the unidirectional causality relationship from export to income. They also found, long run relationship for export, import and income. However, they found no causality relationship between import and income. Rahman [14] suggested that, there was equilibrium relationship among the export, import and economic growth in Malaysia. However, this was not the case in Indonesia.

\section{Capital formation and economic growth}

Several empirical studies which investigated the relationship between fixed capital formation and economic growth found that, fixed capital formation determine the rate of future economic growth. These studies include, Kormendi and Maguire, Barro, De long and summers

${ }^{2}$ Further in more economic sense the term used as capital accumulation which implies total stock of (physical) capital used for investment purposes. Gross fixed capital formation it is classified into two parts, gross private domestic investment and gross public domestic investment. The gross fixed public capital investmen is outcome of government and public enterprises. From this fact reader should be consistent that, in this paper when we use terms capital formation we refer to the domestic investment
[15-17]. However, the study of Kendrick argued that, the rate of capital formation does not guarantee the economic growth. Instead, there should be efficiency in allocation of resources from the low productive to more productive sectors.

Blomstorm et al. [18] found that, capital formation does not cause economic growth, instead the causal direction flows from economic growth to capital formation. Ghali and Al-Mutawa [19] investigated the causality relationship between gross fixed capital formation and economic growth using VAR. The results varied significantly across countries; for the case of Japan and UK there was feedback causality relationship, whilst in USA and France there was unidirectional causality from fixed investment to economic growth. However, for the case of Canada, Germany and Italy the economic growth rate caused fixed capital formation.

In contrast, Ullah et al. [20] found that, GDP does not Granger cause export or capital formation in Pakistan. Instead, they found that, it only Grangers cause real imports. In addition, they found capital formation causes real imports and not real exports. Furthermore, they found no causality relationship between capital formation, export and import. On the other hand, Adhikary [21] found that, capital formation has long run relationship with export and import in Bangladesh. On the other hand, the study found long run causality relationship flows from trade, capital formation and FDI to economic growth. In this way the study concluded that, capital formation has long run relationship and cause economic growth. However, most of these studies have not included export and imports in their models, they are bivariate systems, which results to unreliable suggestions for policies making.

\section{Data and Methodology}

\section{Theoretical frameworks}

On one hand, endogenous growth theory has emphasized the role of imports in economic growth [10,11]. From the theory, it is argued that, imports can absorb foreign technology in domestic economy; it increases the availability of intermediate goods and inputs. This includes machines, human capitals, skilled labors and equipment which in general, can increase productivity in the economy. From this fact, imports received considerable attention in determining the long run economic growth especially for developing countries.

On the other hand, Capital formations refer to the net additions of (physical) capital stock in the economy present the real picture of domestic investment where by the goods and services are produced and growth of "real economy". ${ }^{3}$ Capital formations (investment) can have relationship with the exports, because when the investment demand increased, then the export demand also rised. In the same case, Young argued that, besides export, the rapid increase in economic growth of NICs has been highly contributed by the development of the investment policies.

Theoretically, capital formation can enhance the economic growth through increasing level of capital stock and promoting domestic technology. If this is the case, it is worthwhile to understand that, rise of imports especially of capital goods and inputs foreign technology and intermediate goods can accelerate the capital formations and enhance

${ }^{3}$ Further in more economic sense the term used as capital accumulation which implies total stock of (physical) capital used for investment purposes. Gross fixed capital formation it is classified into two parts, gross private domestic investment and gross public domestic investment. The gross fixed public capital investment is outcome of government and public enterprises. From this fact reader should be bear in mind that in this paper when we use terms capital formation we refer to the domestic investment 
the domestic investment. This would result into expansion of exports and higher economic growth. Therefore, the effect of imports should pass through capital formations (investment).

On the other way around, the increase in exports would result to increase the accumulation of foreign exchange, which in turn will increase imports. This will accelerate capital formations and results to the economic growth. Furthermore, the higher income can initiate the domestic firms to demand more investment and increase productivity, as results increase exports. In fact, both growth theories including neoclassical and endogenous theories have shown that, domestic investment, export and imports reinforce each other in determining the economic growth $[2,10,11,22]$. Furthermore, the growth theories, especially endogenous growth theory show that, export, imports and domestic investment have long run equilibrium relationship with the economic growth. Therefore, we assume the following model:

\section{$\triangle Y(\triangle G R O W T H)=F(\triangle E X P O R T, \triangle I M P O R T, \triangle$ CAPITAL FORMATION)}

We acknowledge that, there are many variables that exist in growth models that can be relevant to this analysis. However, the VAR in multivariate systems requires sufficient number of observations. On the other hand, given lag length, the addition of more variables in the systems can quickly exhaust degree of freedom and make our estimation unreliable [23,24]. Furthermore, since we are only interested in direct relationship between export, import, capital formation and economic growth, we believe that, the inclusion of more variables in VAR analysis would result to confusion in and poor estimation in making inferences [24].

\section{Unit root test}

It is accepted that, most of macroeconomic data are non-stationary in their levels form and their mean and variances tends to diverge overtime. Therefore, we should ensure that these data are stationary by differencing (Yt-Yt-1); otherwise they would results into spurious relationship.

In this case, we are using the ADF test to find the degree of integration of these variables [25-27]. These are the two main tests widely used to find the degree of integration. By using ADF test we consider the following two equations. This test is conducted with and without trends; both tests assume the null hypothesis that there is unit root

$$
\begin{aligned}
& \Delta y_{t}=\alpha o+\alpha y_{t-1}+\sum_{k=1}^{n} \alpha \Delta y_{t-k}+\varepsilon_{t} \\
& \Delta y_{t}=\alpha_{0}+\sum_{k=1}^{n} \alpha \Delta y_{t-k}+\delta_{t}+\varepsilon_{t}
\end{aligned}
$$

Philips Perron test is performed as

$$
\begin{aligned}
& \Delta x_{t}=\beta_{o}+\beta_{2} x_{t-1}+\delta+\varepsilon_{2 t} \\
& \Delta x_{t}=\beta_{o}+\beta_{2} x_{t-1}+\delta+\varepsilon_{2 t}
\end{aligned}
$$

Where $\Delta$ refers to the first difference operator for all equations, $y$ and $x$ are time series data, $t$ is the linear time trend, $n$ is the optimum lag number for the dependent variable which are necessary to make error term serial uncorrelated for equation 1 and 2. $\varepsilon$ is the random error terms, the hypothesis is made for coefficient of $y_{t-1}$ for equations 1 and 2. The same applied to $x_{t-1}$ for equations 3 and 4 .

The insignificant of this coefficient implies that, data are nonstationary in their level form and have no constant mean and variance over time. Equation 1 consists only drift while equation 2 consist both drift and linear time trends. The same case applied for the difference between equations 3 and 4 . The appropriate lag is selected using non correlated residuals.

\section{Cointegration test and vector error correction model (VECM)}

Furthermore, linear combination of two or more non stationary series can be stationary. Furthermore if the stationary behavior exists after linear combinations, then the two or more non stationary series are said to be co integrated [7]. Even though, non-stationary series can have short run deviations. In this case, we tend to seek for the co integration for all included variables in this study, using the most widely used test of Johansen and Juselius test.

The method uses the unrestricted VAR and estimates the following equations

$$
\Delta y_{t}=\beta+\Gamma_{1} \Delta y_{t-1}+\Gamma_{2} \Delta y_{t-2}+\Gamma_{k-1} \Delta y_{t-k-1}+\Gamma y_{t-k}+\mu_{t}
$$

Furthermore, matrix $\Gamma$ contains the information for the long run relationship for the included variables. The rank of co integrating vectors is usually denoted by " $r$ ", therefore the rank of $\Gamma$ determines co integrating vectors of the variables that exist in the equations.

If the rank of $\Gamma$ equals to zero $(r=0)$ this implies that, there is no co integration for the included variables. However, if the rank is equal to one $(r=1)$, it means that, there exists one co integrating vector. However, when the value of $r$ relies in the region of $1<r<\mathrm{n}$, it implies multiple values of co integration vectors. Two likelihood ration test statistics are used in Johansen and Juselius to determine the nature of co integration or co integrating rank [28,29]. These tests are Trace statistics and Maximum Eigen values, the following are the descriptions of the test $\lambda \max =-T \operatorname{In}\left(1-\lambda_{r+1}\right)$, the null hypothesis is $r=k$ co integrating vectors, where $(k=0,1,2,3 \ldots \ldots . . . n)$ against alternative test that $r \leq k+1$. The second test is $\lambda$ trace $=-T \sum_{i=r+1}^{n} \operatorname{In}\left(1-\lambda_{i}\right)$ where null hypothesis is $r=k$ against alternative hypothesis, $r \leq 1$. According to Johansen and Juselius [29] suggested that, trace test might have the problems of lacking power compare to maximum Eigen value. So in this case, basing on the power of the test, the maximum Eigen value is preferred. The whole process of co integration we start by selecting the appropriate lag length using Akaikes and Schwarz criterion.

If variables are integrated of order I (1) and they are co integrated, it implies at least one way of causality [30]. Therefore, if variables are co integrated we should estimate causality relationship under the Vector error correction term, in order to absorb both short run and long run information. However, if the variables are not co integrated, we have to estimate regressions using unrestricted VAR in first difference of the variables and exclude error correction terms, in this case, significance of $\mathrm{F}$ test will give short run causality.

The VECM model is specified as

$$
\Delta n Y Y_{t}=\alpha_{o}+\sum_{t=1}^{n} \beta_{1 i} \Delta h(Y)_{t-i}+\sum_{t=1}^{n} \beta_{2 i} h(E X P)_{t-i}+\sum_{t=1}^{n} \beta_{3 i} h(I M P)_{t-i}+\sum_{t=1}^{n} \beta_{4} h(G F C)_{t-i}+\lambda e_{t-1}+e
$$
$\Delta I n E X P_{t}=\alpha_{o}+\sum_{t=1}^{n} \beta_{1 i} \Delta h(Y)_{t-i}+\sum_{t=1}^{n} \beta_{2 i} h(E X P)_{t-i}+\sum_{t=1}^{n} \beta_{3 i} h(I M P)_{t-i}+\sum_{t=1}^{n} \beta_{4} h(G F C)_{t-i}+\lambda e_{t-1}+e$ $\Delta I n I M P_{t}=\alpha_{o}+\sum_{t=1}^{n} \beta_{1 i} \Delta h(Y)_{t-i}+\sum_{t=1}^{n} \beta_{2 i} h(E X P)_{t-i}+\sum_{t=1}^{n} \beta_{3 i} h(I M P)_{t-i}+\sum_{t=1}^{n} \beta_{4} h(G F C)_{t-i}+\lambda e_{t-1}+e$ $\Delta I n I G C F_{t}=\alpha_{o}+\sum_{i=1}^{n} \beta_{t i} \Delta I n(Y)_{t-i}+\sum_{i=1}^{n} \beta_{2 i} I n(E X P)_{t-i}+\sum_{i=1}^{n} \beta_{3 i} I n(I M P)_{t-i}+\sum_{i=1}^{n} \beta_{4} I n(G F C)_{t-i}+\lambda e_{t-1}+e$

The model helps to avoid short run loss of information. Short run deviations towards long run equilibrium, is adjusted instantly to long 
Citation: Albiman M, Suleiman NN (2016) The Relationship among Export, Import, Capital Formation and Economic Growth in Malaysia. J Glob Econ 4: 186. doi:10.4172/2375-4389.1000186

Page 4 of 6

run equilibrium, therefore the Error correction term helps to correct the proportion of disequilibrium in the next period. The ECM term is represented by coefficient of $\lambda$ if the variables are co integrated.

\section{Data descriptions}

Annual times series data will be collected from 1967-2010 (43 years). Time series data started from 1967 because it is the time when Malaysia joined in ASEAN, and it is the critical period when the outward oriented policies started to emerge .The data will be transformed into $\log$ form to reduce higher disparity for the trends of data. The study expresses the current market price of export of goods and services, import of goods and services, gross fixed capital formation as the ration of GDP at current market prices. Economic growth is proxies by real GDP per capita (constant market price). Besides, capital formation (investment) is presented using gross fixed capital formation according to the studies of $[16,19,21]$.

From this case, the variables will be valued as InY, InEXPGDP, InIMPGDP, InGCFGDP which implies GDP per capital, ration of nominal exports over GDP, ratio of nominal import over GDP, ratio of Gross capital fixed over GDP respectively.

\section{Analysis and Discussions}

\section{Unit root}

Data in Table 1 show that, null hypothesis of GDP (economic growth), IMP (imports), EXP (exports) and LGFCGDP (capital formations) to have unit root, cannot be rejected at $5 \%$ level of significance in both Augmented Dickey Fuller test and Philips-Peron test. Therefore, all variables are non-stationary in level form. This means that mean and variance are not constant. However, in Table 2 the variable becomes stationary I (1) after first difference in both ADF and PP test.

\section{Cointegration results}

From Table 3, using non correlated residuals test for the autocorrelation we found that, the optimum lag is 1 . In general the results indicate that, there is no cointegration among GDP (economic growth), IMP (imports), EXP (exports) and LINVGDP (Capital formations). This implies that, there is no long run relationship between the variables in the case of Malaysia. Meanwhile, the results indicate that the use of VECM is no longer valid since there is no long run relationship. In turn, we have to use VAR in first difference form level form to investigate the short run relationship among the included variable.

\section{Granger causality test}

Data in Table 4 show that the optimum lag selected using non correlated residuals is one. The main findings indicate that, there is unidirectional short run causality from export ratio to import ratio. These findings contradict with the previous literatures in case of Malaysia such as Baharumshah [9]. On the other hand, the results show that, export ratio and economic growth granger cause domestic investment. In the same case, these results contradict with that of Kendric. However, these results are supported by several previous literatures such as Blomstorm et al. [18] and Ghali and Al muttawa [19] who found that, economic growth granger cause domestic investment and not otherwise.

The causal channels can be summarized as seen in the following figure (Figure 1):

\begin{tabular}{|c|c|c|c|c|}
\hline & \multicolumn{2}{|c|}{ ADF test } & \multicolumn{2}{c|}{ PP test } \\
\hline Variables & Constant & $\begin{array}{c}\text { Constant and } \\
\text { Trend }\end{array}$ & Constant & $\begin{array}{c}\text { Constant and } \\
\text { Trend }\end{array}$ \\
\hline LGDP & -0.933498 & -1.674957 & -0.922162 & -1.963498 \\
\hline LIMP & -0.905060 & -1.614941 & -0.948903 & -1.614941 \\
\hline LEXP & -0.346697 & -2.670155 & -0.410891 & -2.739319 \\
\hline LGCFGDP & -2.026219 & -1.786554 & -2.421172 & -1.645562 \\
\hline
\end{tabular}

Note: * indicate significance at $5 \%$ level of significance. The $t$ critical value derived from Mckinnon (1996) tables. ADF refer to Augumented Dickey Fuller test, PP refers to Philips and Perron test.

Table 1: Results of unit root test at level form.

\begin{tabular}{|c|c|c|c|c|}
\hline \multirow{2}{*}{ Variables } & \multicolumn{2}{|c|}{ ADF test } & \multicolumn{2}{c|}{ PP test } \\
\cline { 2 - 5 } & Constant & $\begin{array}{c}\text { Constant and } \\
\text { Trend }\end{array}$ & Constant & $\begin{array}{c}\text { Constant and } \\
\text { Trend }\end{array}$ \\
\hline LGDP & $-6.167062^{*}$ & $-6.164823^{*}$ & $-6.172463^{*}$ & $-6.167062^{*}$ \\
\hline LIMP & $-5.968946^{*}$ & $-5.899691^{*}$ & $-5.922480^{*}$ & $-5.848135^{*}$ \\
\hline LEXP & $-5.796699^{*}$ & $-5.724871^{*}$ & $-5.729759^{*}$ & $-5.646385^{\star}$ \\
\hline LINV & $-5.183434^{*}$ & $-5.217766^{*}$ & $-5.138447^{*}$ & $-5.121788^{*}$ \\
\hline
\end{tabular}

Note: * indicate significance at $5 \%$ level of significance. The $t$ critical value derived from Mckinnon (1999) tables.

Table 2: Results of unit roots after first difference.

\begin{tabular}{|c|c|c|c|c|}
\hline Null & $\begin{array}{c}\text { Trace } \\
\text { statistics }\end{array}$ & $\begin{array}{c}\text { Trace critical } \\
\text { value }\end{array}$ & $\begin{array}{c}\text { Max-Eigen } \\
\text { Statistics }\end{array}$ & $\begin{array}{c}\text { Max-Eigen } \\
\text { critical value }\end{array}$ \\
\hline None & 44.31444 & 47.85613 & 21.03877 & 27.58434 \\
\hline At most 1 & 23.27566 & 29.79707 & 11.65763 & 21.13162 \\
\hline At most 2 & 11.61803 & 15.49471 & 10.87483 & 14.26460 \\
\hline At most 3 & 0.743201 & 3.841466 & 0.743201 & 3.841466 \\
\hline
\end{tabular}

Table 3: Multivariate cointegration test results.

\begin{tabular}{|c|c|c|c|c|}
\hline \multirow{2}{*}{$\begin{array}{c}\text { Dependent } \\
\text { Variable }\end{array}$} & \multicolumn{4}{|c|}{ Independent variable } \\
\cline { 2 - 5 } & LGDPC & LEXPGDP & LIMPGDP & LINVGDP \\
\hline LGDP & - & 0.384 & 3.567 & 0.631 \\
& & $(0.82)$ & $(0.16)$ & $(0.72)$ \\
\hline LEXPGDP & 1.994 & - & 1.222 & 2.353 \\
& $(0.36)$ & & $(0.54)$ & $(0.30)$ \\
\hline LIMPGDP & 0.246 & $9.883^{*}$ & - & 2.914 \\
& $(0.88)$ & $(0.00)$ & & $(0.23)$ \\
\hline LINVGDP & $5.165^{\star *}$ & $4.831^{* *}$ & 2.214 & - \\
& $(0.07)$ & $(0.08)$ & $(0.33)$ & \\
\hline
\end{tabular}

Note: * and ${ }^{* *}$ denotes significant at $5 \%, 10 \%$ significance level, respectively Number in parenthesis ( ) indicate $p$ value

Table 4: Granger causality results.

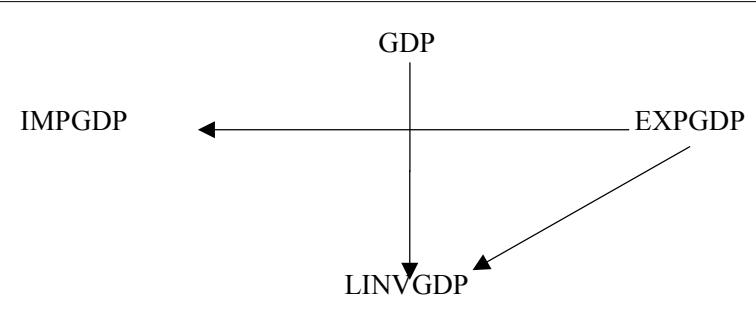

Figure 1: Summary of the causal channels. 
Response to Generalized One S.D. Innovations \pm 2 S.E

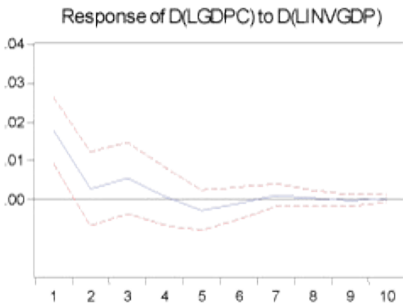

Response of $D(L G D P C)$ to $D(L I M P G D P)$

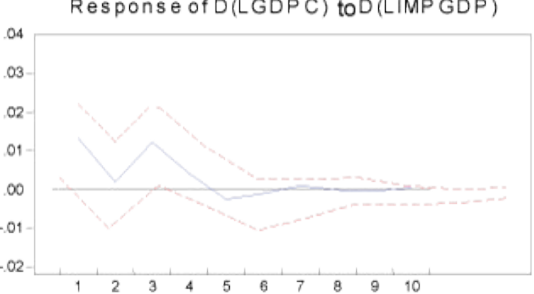

Response of GDP to

EXP

Figure 2: Generalized impulse response.

\section{Impulse response functions}

In impulse response function we disturb system by changing standard deviation of one variable, so as to tress on how other variables will respond. We introduce shocks to independent variables and to simulate the future impact to the dependent variables. Would shock be persistent or significant? There are two identification criteria, cholesky (Recursive) identification or using theoretical identification. However, if variables have higher correlation the third and best method is generalized impulse response. Therefore, before estimating impulse response, to have clear ideas on how to arrange the variables in the system, we checked for correlation matrix ${ }^{4}$. The results indicated that, there is high correlation among the variables, any arrangement of the variables in the system would affect the results. From this point, we used generalized impulse response which is more favored in case, there is higher correlation matrix. From the results of impulse response, the economic growth responds both positive and negative way depending on time period, due to the shock of domestic investment (LINVGDP), Import (LIMPGDP) and export (LEXPGDP) (Figure 2).

\section{Conclusion and Recommendation}

The role of export to economic growth has been examined as seen in several previous empirical literatures. However, the results were country specific and did not indicate general consensus. The major difference that the data have shown is the specification of the model. Some of the previous literatures found that, role of imports are an important additional variable to determine the clear role of export to economic growth. However, theoretical literatures show that, domestic investment is an important aspect in supporting the role of export to economic growth. Yet, few studies have empirically examined the relationship of export, import and domestic investment with the economic growth.

This study used time series data from 1967-2010 and VAR analysis. For the cointegration test we found no long run relationship among the interested variables. For causality analysis, export ratio and economic growth granger cause domestic investment. The impulse response function show that, the economic growth responds both positive and negative way depending on time period, due to the shock of domestic investment, import and export. Meanwhile because Malaysia is an open economy, to ensure effectively utilization of domestic resources, reforms of new policies to ensure that, at least two variables either import, export or domestic investment re enforce each other in promoting economic growth over long run is needed.

${ }^{4}$ The results of correlation matrix were not presented here, they are available upon request from the author.
The presence of no long run relationship among, export, import, domestic investment and economic growth in Malaysia. This implies that in Malaysia, any economic policies to improve export, import, and domestic investment would have no impact to economic growth over the long run. Nevertheless, in the short run export is an important factor in supporting imports in Malaysia. Unfortunately, imports do not have any impact to economic growth. This indicates major problem in economic policies. The government has to ensure that, imports would support economic growth through importing more appropriate goods such as capital goods and machines. Not only that but also, we have seen that, export has direct impact to domestic investment but this impact is not transferred into economic growth. Instead, higher economic growth has direct impact to domestic investment. This implies that, to improve domestic investment in Malaysia, it has to support more economic growth. Major policies have to be reformed to ensure long run impact of export to economic growth. The government has to ensure more promotion of domestic productions through tax reduction, enhancement of more infrastructure development, manufactured products and domestic technology.

The future studies have to include more additional variables such as human capital and technology to investigate the relationship with the economic growth. Furthermore, it is worthwhile to use more appropriate methods that are more robust for short run sample such as ARDL and dynamic ordinary least (DOLS). In addition to that, it is worthwhile to decompose export and import into primary and manufactured goods, so as to investigate their impact to economic growth rather than using total value of export or import.

\section{References}

1. Ricardo D (1817) On the principles of political economy and taxation. John Murray, UK.

2. Solow RM (1956) A contribution to the theory of economic growth. The Quarterly Journal of economics 70: 65-94

3. Balassa B (1978) Exports and economic growth: Further evidence. Journal of Development Economics 5: 181-18.

4. Helpman E, Krugman P (1985) Market structure and foreign trade. Increasing returns, imperfect competition, and the International economy. MIT Press, USA

5. Grossman GM, Helpman E (1991) Growth and welfare in a small open economy. In: Helpman E, Razing A (eds.). International Trade and Trade Policy. MIT Press, USA.

6. World Bank (1993) The East Asian Miracle: Economic growth and public policy. Oxford University Press, UK.

7. Engle RF, Granger CWJ (1987) Co-integration and error correction: Representation, estimation and testing. Econometrica 55: 251-276. 
Citation: Albiman M, Suleiman NN (2016) The Relationship among Export, Import, Capital Formation and Economic Growth in Malaysia. J Glob Econ 4: 186. doi:10.4172/2375-4389.1000186

Page 6 of 6

8. Riezman RG, Whiteman H, Peter SM (1996) The Engine of growth or its handmaiden? A time-series assessment of export-led growth. Empirical Economics. Springer 21: 77-110.

9. Baharumshah AZ, Rashid S (1999) Exports import and economic growth in Malaysia: Empirical evidence based on Multivariate time series. Asian Economic Journal 13: 389-406.

10. Romer PM (1986) Increasing return and long run growth. Journal of political economy 95: 1002-1037.

11. Lucas RE (1988) On the mechanisms of economic development. Journal of Monetary Economics 22: 3-42.

12. Awokuse TO (2007) Causality between exports, imports, and economic growth: Evidence from transition economies. Economics Letters 94: 389-395.

13. Hossain $H$, Jabin (2009) Dynamic and causality among export, import and income in Bangladesh .The Bangladesh Development studies 32: 101-113.

14. Rahman M (2011) Existence of export-import cointegration: A study on Indonesia and Malaysia. International Journal of Business and Research 4: 108-115.

15. Kormendi RC, Maguire PJ (1985) Macroeconomic determinants of growth: Cross country evidence. Journal of Monetary Economics 16: 141-163.

16. Barro RJ (1991) Economic growth in a cross section of countries. Quarterly Journal of Economics 106: 407-443

17. De Long JB, Andsummer L (1991) Equipment, investment and economic growth. Quarterly Journal of Economics 106: 445-502.

18. Blomstrom M, Lipsey R, Zejan M (1994) What explains the developing countries growth? Oxford University Press, UK.

19. Ghali KH, Al-Mutawa A (1999) The intertemporal causal dynamics between fixed capital formation and economic growth in the group of seven countries. International Economic Journal 13: 31-37.
20. Ullah S, Zaman BU, Farooq M, Javid A (2009) Cointegration and causality between exports and economic growth in Pakistan. European Journal of Socia Science 10: 264-272.

21. Adhikary BK (2011) FDI, trade openness, capital formation and economic growth in Bangladesh: A linkage analysis. International Journal of Business and Management 6: 17-27.

22. Solow RM (1957) Technical change and the aggregate productions. Reviews of Economic and statistics 39: 312-320.

23. Mansor HI (2007) The yen dollar exchange rate and Malaysia macroeconomic dyanamics. Developing Economies 45: 315-338.

24. Konya L (2006) Exports and growth: granger causality analysis on OECD countries with a panel data approach. Journal of Economic modeling 23: 978-992.

25. Dickey DA, Fuller WA (1979) Distribution of the estimator for autoregressive time series with a unit root. Journal of the American Statistical Association 74 427-431.

26. Dickey D, Fuller W (1981) Likelihood ratio statistics for autoregressive time series with a unit root. Econometrica 49: 1057-1072.

27. Phillips PCB, Perron $P$ (1988) Testing for a unit root in time series regression. Biometrika 75: 335-346.

28. Johansen S (1988) Statistical analysis of co integrating vectors. Journal of Economic Dynamics and Control 12: 231-254.

29. Johansen S, Juselius K (1990) Maximum likelihood estimation and inference on co integration with applications to the demand for money. Oxford Bulletin of Statistics 52: 169-210

30. Granger CWJ (1988) Some recent developments in a concept of causality Journal of Econometrics 39: 199-211. 